\title{
A novel and an efficient catalyst for one-pot synthesis of 2,4,5- trisubstituted imidazoles by using microwave irradiation under solvent-free conditions
}

\author{
JAVAD SAFARI*, SHIVA DEHGHAN KHALILI and SAYED HOSSEIN BANITABA \\ Laboratory of Organic Chemistry Research, Department of Organic Chemistry, College of Chemistry, \\ University of Kashan, 87317-51167, Kashan, IR Iran \\ e-mail: safari@kashanu.ac.ir
}

MS received 5 August 2009; revised 11 January 2010; accepted 19 February 2010

\begin{abstract}
NH}_{4}\right)_{6} \mathrm{Mo}_{7} \mathrm{O}_{24} \cdot 4 \mathrm{H}_{2} \mathrm{O}$ has been used as an efficient catalyst for an improved and rapid synthesis of 2,4,5-trisubstituted imidazoles by a three-component, one-pot condensation of benzil, aryl aldehydes and ammonium acetate in good yields under solvent-free conditions using microwave irradiation. The reactions in conventional heating conditions were compared with the microwave-assisted reactions.
\end{abstract}

Keywords. 2,4,5-Trisubstituted imidazoles; ammonium heptamolybdate tetrahydrate; one-pot condensation; microwave irradiation; solvent-free conditions.

\section{Introduction}

The toxicity and volatile nature of many organic solvents, particularly chlorinated hydrocarbons that are widely used in huge amounts for organic reactions have posed a serious threat to the environment. ${ }^{1}$ Thus, the design of solvent-free catalytic reaction has received more attention in recent times in the area of green synthesis. ${ }^{2,3}$ The emergence of microwave technology as a tool for increasing reaction rates is well documented. ${ }^{4,5}$ Microwave-assisted reactions are extremely attractive to synthetic organic chemists due to their ability to shorten reaction times and in some cases improve regio-and/ or chemoselectivity. ${ }^{6,7}$ Reactions that previously required hours to run for completion can now be finished within minutes. ${ }^{8}$ Imidazoles are commonly utilized substructures within the pharmaceutical industry, as these heterocycles impart unique physical and biological properties to compounds of interest. ${ }^{9-13}$ Trisubstituted imidazole derivatives are widely used as organic materials, such as to resist composition on textile, ${ }^{14}$ fluorescent whiteners on textile, ${ }^{15}$ photographic materials, ${ }^{16-18}$ electroluminescent materials $^{19,20}$ and optical materials. ${ }^{21,22}$ Meantime, it was found that these compounds play roles in many kinds of biological activities. ${ }^{23-25}$ This versatile

\footnotetext{
*For correspondence
}

applicability highlights the importance of access to efficient synthetic routes to well-designed and highly substituted imidazole derivatives. There are several methods for the synthesis of highly substituted imidazoles. ${ }^{26}$ A number of methods have been developed for the synthesis of 2,4,5-trisubstituted imidazoles. 2,4,5-Trisubstituted imidazoles are generally synthesized by three-component cyclocondensation of a 1,2-diketone, $\alpha$-hydroxyketone or $\alpha$ ketomonoxime with an aldehyde and ammonium acetate, which comprise the use of microwaves, ${ }^{27-30}$ ionic liquids, ${ }^{31-35}$ refluxing in acetic acid, ${ }^{36-38}$ silica sulfuric acid, ${ }^{39,40} \mathrm{NiCl}_{2} \cdot 6 \mathrm{H}_{2} \mathrm{O} / \mathrm{Al}_{2} \mathrm{O}_{3},{ }^{41} \mathrm{Yb}(\mathrm{OTf})_{3},{ }^{42}$ $\mathrm{Yb}(\mathrm{OPf})_{3},{ }^{43}$ iodine, ${ }^{44} \mathrm{Zr}(\mathrm{acac}){ }_{4},{ }^{45} \mathrm{InCl}_{3} \cdot 3 \mathrm{H}_{2} \mathrm{O},{ }^{46}$ heteropolyacid, ${ }^{47}$ sodium bisulfite, ${ }^{48}$ potassium aluminum sulfate (alum), ${ }^{49}$ ceric ammonium nitrate $(\mathrm{CAN}){ }^{50,51}$ polymer-supported $\mathrm{ZnCl}_{2}{ }^{52}$ and $\mathrm{L}-$ proline. ${ }^{53}$ Moreover, they have also been prepared by the addition of a substituted amino alcohol to a thioamide and subsequent oxidation with $\mathrm{PDC}^{54}$ or by the reaction of aryl nitriles and $\alpha, \alpha$-dilithioarylnitromethanes ${ }^{55}$ or by multistep syntheses ${ }^{56,57}$. Khodaei and co-workers in 2007 described the synthesis of 2,4,5-trisubstituted imidazoles from 1,2diketone or $\alpha$-hydroxyketone, aldehyde and ammonium heptamolybdate tetrahydrate in tetrabutylammonium iodide using catalytic amounts of $p$-TSA. ${ }^{58}$ Despite their potential utility, most of these synthetic methods suffer from one or more serious 
drawbacks, such as laborious and complex work-up and purification, significant amounts of waste materials, strongly acidic conditions, occurrence of side reactions, low yields, high temperature, long reaction time and the use of expensive reagents. We were promoted a facile, mild and efficient method for one-pot synthesis of 2,4,5-trisubstituted imidazole derivatives starting from 1,2-diketone and various aromatic aldehydes under solvent-free and microwave conditions in the presence of $\left(\mathrm{NH}_{4}\right)_{6}$ $\mathrm{Mo}_{7} \mathrm{O}_{24} \cdot 4 \mathrm{H}_{2} \mathrm{O}$ as catalyst (figure 1).

\section{Experimental}

\subsection{Materials}

Chemical reagents were purchased from the Merck Chemical Company in high purity. All the materials were of commercial grade reagent.

\subsection{Apparatus}

Melting points were determined in an open capillaries using an Electrothermal Mk3 apparatus. Infrared (IR) spectra were recorded using a Perkin-Elmer FTIR 550 spectrometer. ${ }^{1} \mathrm{H}$ NMR and ${ }^{13} \mathrm{C}$ NMR spectra were recorded in DMSO- $d_{6}$ using Bruker DRX-400 spectrometer at 400 and $100 \mathrm{MHz}$ respectively. The elemental analyses $(\mathrm{C}, \mathrm{H}, \mathrm{N})$ were obtained from a Carlo ERBA Model EA 1108 analyzer carried out on Perkin-Elmer 240c analyzer. UV spectra were recorded on a Hitachi 200-20 spectrophotometer using spectrophotometeric grade chloroform (Baker). Microwave synthesis was carried out on a ETHOS 1600 , Milestone microwave reactor.

\subsection{General procedure for synthesis of 2,4,5-} trisubstituted imidazoles under conventional heating conditions

Benzil $(0.21 \mathrm{~g}, 1 \mathrm{mmol})$, ammonium acetate $(0.15 \mathrm{~g}$, $2 \mathrm{mmol})$, aldehyde $(1 \mathrm{mmol})$ and $\left(\mathrm{NH}_{4}\right)_{6} \mathrm{Mo}_{7} \mathrm{O}_{24} \cdot 4 \mathrm{H}_{2} \mathrm{O}$

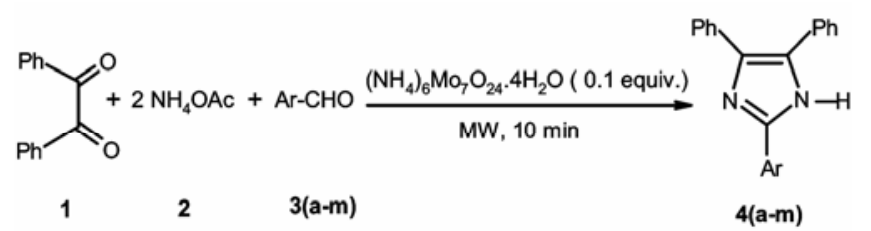

Figure 1. $\left(\mathrm{NH}_{4}\right)_{6} \mathrm{Mo}_{7} \mathrm{O}_{24} \cdot 4 \mathrm{H}_{2} \mathrm{O}$ catalysed synthesis of 2,4,5-trisubstituted imidazoles under microwave irradiation.
$(0.12 \mathrm{~g}, 0.1 \mathrm{mmol})$ were placed in a round bottom flask. The reactants were mixed and heated at $100^{\circ} \mathrm{C}$. The progress of the reaction was monitored by TLC (ethyl acetate/petroleum ether $=3: 7$ ). After completion the reaction mixture was washed with cool water and filtered. The solid residue was then crystallized from 9:1 acetone-water solution. Pure product was obtained as crystalline in good yields. Most of the products are known and were identified by comparing with their physical and spectral data with those of authentic samples.

2.4 General procedure for synthesis of 2,4,5trisubstituted imidazoles under microwave irradiation

A mixture of benzil $(0.21 \mathrm{~g}, 1 \mathrm{mmol})$, ammonium acetate $(0.15 \mathrm{~g}, 2 \mathrm{mmol})$, aldehyde $(1 \mathrm{mmol})$ and $\left(\mathrm{NH}_{4}\right)_{6} \mathrm{Mo}_{7} \mathrm{O}_{24} .4 \mathrm{H}_{2} \mathrm{O}(0 \cdot 12 \mathrm{~g}, 0 \cdot 1 \mathrm{mmol})$ put in the hole of the microwave reactor. The mixture was irradiated at $100 \mathrm{~W}$ for $10 \mathrm{~min}$. The progress of the reaction was monitored by TLC (ethyl acetate/ petroleum ether $=3: 7$ ). After cooling, the reaction mixture was washed with cool water and filtered. The solid residue was then crystallized from $9: 1$ acetone-water solution. Pure product was obtained in good yields.

\subsection{Spectral data for new derivatives of 2,4,5- trisubstituted imidazoles}

2.5a 2-(3-methoxyphenyl)-4,5-diphenyl-1H-imidazole (4b): m.p.: $259-262^{\circ} \mathrm{C}$; IR $\left(\mathrm{cm}^{-1}, \mathrm{KBr}\right)$ : $3431.80, \quad 3058.38, \quad 2926.27, \quad 1591.31, \quad 1482.73$, 1241.06, 768.39, 686.84; UV $\left(\mathrm{CDCl}_{3}\right): \lambda_{\max }=314$, $240 \mathrm{~nm} ;{ }^{1} \mathrm{H}$ NMR $\left(400 \mathrm{MHz}\right.$, DMSO- $\left.d_{6}\right): \delta=12.70$ $(s, 1 \mathrm{H}, \mathrm{NH}), 6 \cdot 80-7.80(m, 14 \mathrm{H}, \mathrm{Ar}-\mathrm{H}), 3.80(s, 3 \mathrm{H}$, OMe) ppm; ${ }^{13} \mathrm{C}$ NMR $\left(100 \mathrm{MHz}\right.$, DMSO- $\left.d_{6}\right)$ : $\delta=160 \cdot 00,145 \cdot 86,137 \cdot 63,135 \cdot 60,132 \cdot 15,130 \cdot 27$, $129 \cdot 20,128 \cdot 86,127 \cdot 70,118 \cdot 13,114 \cdot 70,110 \cdot 70$, 55.70 ppm; Anal. Calcd. for $\mathrm{C}_{22} \mathrm{H}_{18} \mathrm{~N}_{2} \mathrm{O}$ : C, 80.96; H, 5.56; N, 8.58. Found: C, 80.94; H, 5.55; N, 8.57.

2.5b 2-(2-naphthyl)-4,5-diphenyl-1H-imidazole (4g): m.p.: $273-276^{\circ} \mathrm{C}$; IR ( $\left.\mathrm{cm}^{-1}, \mathrm{KBr}\right): 3429 \cdot 00,3054 \cdot 16$, $1600 \cdot 50,1500 \cdot 35,1447 \cdot 26,752 \cdot 89,697 \cdot 10 ; \quad$ UV $\left(\mathrm{CDCl}_{3}\right): \quad \lambda_{\max }=330, \quad 288, \quad 244 \mathrm{~nm} ; \quad{ }^{1} \mathrm{H} \quad \mathrm{NMR}$ $\left(400 \mathrm{MHz}, \mathrm{DMSO}-d_{6}\right): \delta=12.80(s, 1 \mathrm{H}, \mathrm{NH}), 8.61$ $(s, 1 \mathrm{H}, \operatorname{Ar}-\mathrm{H}), 8.25\left(d, 1 \mathrm{H},{ }^{3} J=8.00 \mathrm{~Hz}, \mathrm{Ar}-\mathrm{H}\right)$, 7.92-8.02 (m, 3H, Ar-H), 7.53-7.61 (m, 6H, Ar-H), $7.46\left(t, 2 \mathrm{H},{ }^{3} J=7.90 \mathrm{~Hz}, \quad\right.$ Ar- $), 7.39(t, 1 \mathrm{H}$, 
Table 1. Synthesis of 2,4,5-trisubstituted imidazoles in the presence of various catalysts ${ }^{\mathrm{a}}$.

\begin{tabular}{llccc}
\hline Entry & Catalyst & Time $(\mathrm{min})$ & Temperature $\left({ }^{\circ} \mathrm{C}\right)$ & Yield \\
\hline 1 & None & 30 & 100 & 25 \\
2 & $\left(\mathrm{NH}_{4}\right)_{6} \mathrm{Mo}_{7} \mathrm{O}_{24} \cdot 4 \mathrm{H}_{2} \mathrm{O}$ & 20 & 100 & 80 \\
3 & $\mathrm{VCl}_{3}$ & 20 & 100 & 45 \\
4 & $\mathrm{ZrCl}_{4}$ & 20 & 100 & 50 \\
5 & $\mathrm{WCl}_{6}$ & 20 & 100 & 48 \\
6 & $\mathrm{AlCl}_{3}$ & 20 & 100 & 42 \\
\hline
\end{tabular}

${ }^{\mathrm{a}}$ One equiv. benzil 1, 1 equiv. benzaldehyde 3a, 2 equiv. $\mathrm{NH}_{4} \mathrm{OAc} 2$ and $0 \cdot 1$ equiv. catalyst.

Table 2. Optimization of reaction conditions for synthesis of 2,4,5-trisubstituted imidazoles ${ }^{\mathrm{a}}$.

\begin{tabular}{ccccc}
\hline Entry & $\begin{array}{c}\left(\mathrm{NH}_{4}\right)_{6} \mathrm{Moo}_{7} \mathrm{O}_{24} \cdot 4 \mathrm{H}_{2} \mathrm{O} \\
(\mathrm{mmol})\end{array}$ & Temperature $\left({ }^{\circ} \mathrm{C}\right)$ & Time (min) & Yield (\%) \\
\hline 1 & $0 \cdot 0$ & 60 & 60 & 10 \\
2 & $0 \cdot 05$ & 60 & 35 & 35 \\
3 & $0 \cdot 1$ & 60 & 35 & 50 \\
4 & $0 \cdot 2$ & 60 & 35 & 50 \\
5 & $0 \cdot 0$ & 80 & 45 & 20 \\
6 & $0 \cdot 05$ & 80 & 25 & 47 \\
7 & $0 \cdot 1$ & 80 & 25 & 60 \\
8 & $0 \cdot 2$ & 80 & 25 & 60 \\
9 & $0 \cdot 0$ & 100 & 30 & 25 \\
10 & $0 \cdot 05$ & 100 & 20 & 58 \\
11 & $0 \cdot 1$ & 100 & 20 & 80 \\
12 & $0 \cdot 2$ & 100 & 20 & 80 \\
13 & $0 \cdot 0$ & 130 & 20 & 40 \\
14 & $0 \cdot 05$ & 130 & 20 & 60 \\
15 & $0 \cdot 1$ & 130 & 20 & 80 \\
16 & $0 \cdot 2$ & 130 & 20 & 80 \\
\hline
\end{tabular}

${ }^{\mathrm{a}}$ One equiv. benzil 1: 1 equiv. benzaldehyde 3a: 2 equiv. $\mathrm{NH}_{4} \mathrm{OAc} \mathbf{2}$.

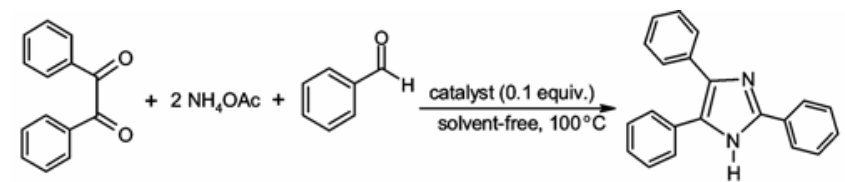

Figure 2. Catalysed synthesis of 2,4,5-triphenyl-1Himidazole under conventional heating conditions.

$\left.{ }^{3} J=7.60 \mathrm{~Hz}, \mathrm{Ar}-\mathrm{H}\right), 7.32\left(t, 2 \mathrm{H},{ }^{3} J=7.90 \mathrm{~Hz}, \mathrm{Ar}-\right.$ $\mathrm{H}), 7.24\left(t, 1 \mathrm{H},{ }^{3} \mathrm{~J}=7.60 \mathrm{~Hz}, \mathrm{Ar}-\mathrm{H}\right) \mathrm{ppm} ;{ }^{13} \mathrm{C}$ NMR $\left(100 \mathrm{MHz}, \mathrm{DMSO}-d_{6}\right): \delta=146 \cdot 00,137.90,135.60$, $133.50,132.20,131.50,129 \cdot 10,129.00,128.90$, $128 \cdot 70,128 \cdot 60,128 \cdot 30,128 \cdot 20,127 \cdot 60,127 \cdot 10$, $127 \cdot 00,126 \cdot 80,124 \cdot 10,123.90 \mathrm{ppm}$; Anal. Calcd. for $\mathrm{C}_{25} \mathrm{H}_{18} \mathrm{~N}_{2}$ : C, 86.68; H, 5.24; N, 8.09. Found: C, $86 \cdot 66 ; \mathrm{H}, 5 \cdot 22 ; \mathrm{N}, 8 \cdot 08$.

\section{Results and discussion}

In this study, to choose the appropriate catalyst some of the Lewis acids such as $\mathrm{AlCl}_{3}, \mathrm{WCl}_{6}, \mathrm{ZrCl}_{4}$, $\mathrm{VCl}_{3}$ were selected. Then, a comparative study was made by using benzaldehyde, benzil and ammonium acetate in the presence of these materials as catalyst (figure 2). The samples were heated under conventional conditions at $100^{\circ} \mathrm{C}$ in the presence of each catalysts, separately. The corresponding results are summarized in table 1 . The results indicated that $\left(\mathrm{NH}_{4}\right)_{6} \mathrm{Mo}_{7} \mathrm{O}_{24} \cdot 4 \mathrm{H}_{2} \mathrm{O}$ was the best catalyst and consequently it was selected for subsequent experiments. In the absence of catalyst, the yield of the product was found to be very low. In the course of this study we found that $\left(\mathrm{NH}_{4}\right)_{6} \mathrm{Mo}_{7} \mathrm{O}_{24} \cdot 4 \mathrm{H}_{2} \mathrm{O}$ was the most effective catalyst in obtaining the yield of triphenylimidazole $(80 \%)$. The catalytic activity of 
Table 3. $\left(\mathrm{NH}_{4}\right)_{6} \mathrm{Mo}_{7} \mathrm{O}_{24} \cdot 4 \mathrm{H}_{2} \mathrm{O}$ catalysed synthesis of 2,4,5-trisubstituted imidazoles under solvent-free conditions.

\begin{tabular}{|c|c|c|c|c|c|c|c|}
\hline \multirow[b]{2}{*}{ Entry } & \multirow[b]{2}{*}{ Aldehyde } & \multirow[b]{2}{*}{$\mathrm{Ar}$} & \multirow[b]{2}{*}{ Product } & \multicolumn{2}{|c|}{ Yield $(\%)^{\mathrm{a}}$ Time (min) } & \multicolumn{2}{|c|}{ M.p. $\left({ }^{\circ} \mathrm{C}\right)$} \\
\hline & & & & $\Delta^{\mathrm{b}}$ & $\mathrm{MW}^{\mathrm{c}}$ & Found & Reported \\
\hline 1 & $3 \mathbf{a}$ & $\mathrm{C}_{6} \mathrm{H}_{5}$ & $4 a$ & $80(20)$ & $94(10)$ & $270-272$ & $272-273^{\mathrm{f}}$ \\
\hline 2 & $\mathbf{3 b}$ & $m-\mathrm{MeOC}_{6} \mathrm{H}_{4}$ & $4 b$ & $78(15)$ & $93(10)$ & $259-262$ & - \\
\hline 3 & $3 c$ & $p-\mathrm{MeC}_{6} \mathrm{H}_{4}$ & $4 c$ & $85(25)$ & $98(10)$ & $230-233$ & $232-235^{\mathrm{d}}$ \\
\hline 4 & 3d & $p-\mathrm{ClC}_{6} \mathrm{H}_{4}$ & $4 d$ & $79(20)$ & $94(10)$ & $260-261$ & $262-264^{\mathrm{d}}$ \\
\hline 5 & $3 \mathbf{e}$ & $m-\mathrm{ClC}_{6} \mathrm{H}_{4}$ & $4 e$ & $78(20)$ & $94(10)$ & $282-283$ & $285-287^{\mathrm{d}}$ \\
\hline 6 & $3 f$ & $p-\mathrm{MeOC}_{6} \mathrm{H}_{4}$ & $4 f$ & $87(25)$ & $99(10)$ & $228-231$ & $230-232^{\mathrm{d}}$ \\
\hline 7 & $3 g$ & 2-Naphthyl & $4 \mathrm{~g}$ & $78(20)$ & $94(10)$ & $273-276$ & - \\
\hline 8 & $3 h$ & $2,4-\mathrm{Cl}_{2} \mathrm{C}_{6} \mathrm{H}_{3}$ & $4 h$ & $77(30)$ & $93(10)$ & $170-172$ & $174-176^{\mathrm{d}}$ \\
\hline 9 & $3 \mathbf{i}$ & 2-Thienyl & $4 i$ & $78(20)$ & $92(10)$ & $261-264$ & $262-266^{\mathrm{d}}$ \\
\hline 10 & $3 \mathbf{j}$ & $p-\mathrm{BrC}_{6} \mathrm{H}_{4}$ & $4 \mathbf{j}$ & $79(20)$ & $93(10)$ & $263-265$ & $261-263^{\mathrm{d}}$ \\
\hline 11 & $3 \mathbf{k}$ & $m-\mathrm{O}_{2} \mathrm{NC}_{4} \mathrm{H}_{6}$ & $4 \mathbf{k}$ & $74(15)$ & $89(10)$ & $269-271$ & $265-267^{\mathrm{f}}$ \\
\hline 12 & 31 & $o-\mathrm{HOC}_{4} \mathrm{H}_{6}$ & 41 & $76(30)$ & $91(10)$ & $198-201$ & $203-205^{\mathrm{f}}$ \\
\hline 13 & $3 m$ & $p-(\mathrm{Me})_{2} \mathrm{NC}_{6} \mathrm{H}_{4}$ & $4 m$ & $82(25)$ & $96(10)$ & $255-257$ & $257-258^{\mathrm{e}}$ \\
\hline
\end{tabular}

${ }^{\mathrm{a}}$ Isolated yield based on aldehyde, ${ }^{\mathrm{b}}$ Under classical heating conditions at $100{ }^{\circ} \mathrm{C},{ }^{\mathrm{c}}$ Using microwave irradiation, ${ }^{\mathrm{d}}$ Ref. $24,{ }^{\mathrm{e}}$ Ref. $42,{ }^{\mathrm{f}}$ Ref. 44.

$\left(\mathrm{NH}_{4}\right)_{6} \mathrm{Mo}_{7} \mathrm{O}_{24} \cdot 4 \mathrm{H}_{2} \mathrm{O}$ is remarkable for both quantitative and qualitative advantages such as cheap availability and non-toxicity.

To optimize the reaction conditions, the reaction of benzaldehyde, benzil and ammonium acetate was used as a model reaction (table 2). In the following study, we examined the reaction at different temperature to find out the effect on the reaction. It was found that at lower temperature, even if the reaction time was prolonged, it gave only low yield, and higher the temperature, higher the yield. The efficiency of the reaction is mainly affected by the amount of catalyst and temperature. As indicated in table 2 , the best results have been obtained at $100^{\circ} \mathrm{C}$ with $0 \cdot 1 \mathrm{mmol}\left(\mathrm{NH}_{4}\right)_{6} \mathrm{Mo}_{7} \mathrm{O}_{24} \cdot 4 \mathrm{H}_{2} \mathrm{O}$. Increasing the amount of $\left(\mathrm{NH}_{4}\right)_{6} \mathrm{Mo}_{7} \mathrm{O}_{24} \cdot 4 \mathrm{H}_{2} \mathrm{O}$ and temperature has not shown in the increase of yield.

For more examination of the influence of microwave irradiation on the reaction, a comparison was made between microwave irradiation and heating conditions. The successful results of $\left(\mathrm{NH}_{4}\right)_{6} \mathrm{Mo}_{7} \mathrm{O}_{24}$. $4 \mathrm{H}_{2} \mathrm{O}$ catalysed syntheses of 2,4,5-trisubstituted imidazoles under solvent-free classical heating conditions or using microwave irradiation are given in table 3. As shown, microwave irradiation has shown better yields and especially in the reaction times. Also, it is observed that by using a wide range of aromatic aldehydes all imidazoles were obtained in moderate to good yields. Therefore, this is a general method that tolerates both electron-withdrawing and electron-donating constituents. The yield of products for $p-\mathrm{MeOC}_{6} \mathrm{H}_{4}$ and $p-\mathrm{MeC}_{6} \mathrm{H}_{4}$ (table 3, entry 3,6) are higher than other aromatic aldehydes. For some of the aromatic aldehydes with high electronwithdrawing and steric effects such as $p-\mathrm{O}_{2} \mathrm{NC}_{6} \mathrm{H}_{5}$ and $2,6-\mathrm{Cl}_{2} \mathrm{C}_{6} \mathrm{H}_{4}$, no reaction took place. The structure of the 2,4,5-trisubstituted imidazole products have been confirmed by their spectroscopic data and their melting points compared with literature reports. The presence of signal at $3400-3430 \mathrm{~cm}^{-1}$ in IR spectra and $12.5-12.8 \mathrm{ppm}$ in ${ }^{1} \mathrm{H}$ NMR spectra, due to $\mathrm{NH}$ related to the imidazole ring are observed.

\section{Conclusions}

In summary, we presented an efficient, mild and rapid approach for the synthesis of 2,4,5trisubstituted imidazoles via condensation of a representative 1,2-diketone (benzil) with various aromatic aldehydes and ammonium acetate, by using $\left(\mathrm{NH}_{4}\right)_{6} \mathrm{Mo}_{7} \mathrm{O}_{24} \cdot 4 \mathrm{H}_{2} \mathrm{O}$ as a new and highly effective catalyst under solvent-free and microwave conditions. Non-corrosiveness, safe, low waste, easy for separation, short time, high yields and environmentally benign are some of the advantages of this methodology.

\section{Acknowledgements}

We gratefully acknowledge the financial support from the Research Council of University of Kashan. We also thank from Dr F Davar for her helpful comments. 


\section{References}

1. Nelson W M 1998 Green Chemistry (ed.) P T Williamson (Oxford: Oxford University Press) p. 200

2. Tanaka K and Toda F 2000 Chem. Rev. 1001025

3. Cave G W V, Raston C L and Scott J L 2001 Chem. Commun. 2159

4. Roberts B A and Strauss C R 2005 Acc. Chem. Res. 38653

5. Olofsson K, Hallberg A and Larhed A 2002 Transition metal catalysis and microwave flash heating in organic chemistry (ed.) A Loupy (Germany: WileyVCH, Weinheim) p. 379

6. De La Hoz A, Diaz-Ortiz A and Moreno A 2004 Curr. Org. Chem. 8903

7. Xu G and Wang Y G 2004 Org. Lett. 6985

8. Kappe C O 2004 Angew. Chem. Int. Ed. 436250

9. Bunnage M E and Owen D R 2008 Curr. Opin. Drug Discovery Dev. 11480

10. Laufer S A, Wagner G K, Kotschenreuther D A and Albrecht W 2003 J. Med. Chem. 463230

11. Ganellin C R, Fkyerat A, Bang-Anderson B, Athmani S, Tertiuk W, Garbarg M, Ligneau X and Schwartz J C 1996 J. Med. Chem. 393806

12. Weinreb S M 2007 Nat. Prod. Rep. 24931

13. Jin Z 2006 Nat. Prod. Rep. 23464

14. Watanabe T, Kinsho T and Hasegawa K 2004 US 234 884 A1

15. Siegrist A, Liechti P, Maeder E and Meyer H R 1973 CH 542266

16. Etou K, Nanhei M and Tanaka S 1983 US 4405705

17. Meji I and Fukui M 1995 JP 07005628 A2

18. Heinrich O L, Hans L B and Uwe D B 2002 US 6451 $520 \mathrm{~B} 1$

19. Dodabalapur A, Strukelj M and Jordan R 1997 EP 763965 A2

20. Mataka S and Hatta T 2005 WO 085208 Al

21. Gostev F E, Kol'tsova L S, Petrukhin A N, Titov A A, Shiyonok A I and Zaichenko N L 2003 J. Photochem. Photobiol. A. Chem. 15615

22. Park S, Kwon $\mathrm{O} \mathrm{H}$ and Kim S $2005 \mathrm{~J}$. Am. Chem. Soc. 12710070

23. Lee J C, Laydon J T and Mcdonnell P C 1994 Nature 372739

24. Lombardino J G 1972 DE 2155558 [1973 US 3772 441]

25. Mitani A, Ichinari D, Saiga M, Hamamura $H$ and Sugiura T 2000 JP 273088 A2

26. Grimmet M R 1984 in Comprehensive heterocyclic chemistry (eds) A R Katritzky and C W Rees (London: Pergamon Press) vol. 5, p. 374

27. Usyatinsky A Y and Khemelnitsky Y L 2000 Tetrahedron Lett. 415031

28. Wolkenberg S E, Wisnoski D D, Leister W H, Wang Y, Zhao Z and Lindsley C W 2004 Org. Lett. 61453

29. Sparks R B and Combs A P 2004 Org. Lett. 62473
30. Oskooie H A, Alimohammadi Z and Heravi M M 2006 Heteroatom Chem. 17699

31. Siddiqui S A, Narkhede U C, Palimkar S S, Daniel T, Lahoti R J and Srinivasan K V 2005 Tetrahedron 61 3539

32. Xia M and Lu Y 2007 J. Mol. Catal. A: Chem. 265205

33. Chary M V, Keerthysri N C, Vupallapati S, Lingaiah $\mathrm{N}$ and Kantevari S 2008 Catal. Commun. 92013

34. Shaabani A, Rahmati A, Aghaaliakbari B and SafaeiGhomi J 2006 Synth. Commun. 3665

35. Khosropour A R 2008 Can. J. Chem. 86264

36. Wang J, Mason R, Derveer D V, Feng K and Bu X R 2003 J. Org. Chem. 685415

37. Sarshar S, Siev D and Mjalli M M 1996 Tetrahedron Lett. 37835

38. Gallagher T F, Seibel G L, Kassis S and Laydon J T 1997 Bioorg. Med. Chem. 549

39. Shaabani A and Rahmati A 2006 J. Mol. Catal. A: Chem. 249246

40. Shaabani A, Rahmati A, Farhangi E and Badri Z 2007 Catal. Commun. 81149

41. Heravi M M, Bakhtiari K, Oskooie H A and Taheri S 2007 J. Mol. Catal. A: Chem. 263279

42. Wang L, Wang Y, Tian H, Yao Y, Shao J and Liu B 2006 J. Fluorine. Chem. 1271570

43. Shen M, Cai C and Yi W 2008 J. Fluorine Chem. 129 541

44. Kidwai M, Mothsra P, Bansal V, Somvanshi R K, Ethayathulla A S, Dey S and Singh T P $2007 \mathrm{~J}$. Mol. Catal. A: Chem. 265177

45. Khosropour A R 2008 Ultrason. Sonochem. 15659

46. Sharma S D, Hazarika P and Konwar D 2008 Tetrahedron Lett. 492216

47. Heravi M M, Sadjadi S, Oskooie H A, Hekmatshoar $\mathrm{R}$ and Bamoharram F F 2008 J. Chin. Chem. Soc. 55 1199

48. Sangshetti J N, Shinde D B, Kokare N D and Kotharkar S A 2008 Monatsh. Chem. 139125

49. Mohamadi A A, Mivechi M and Kefayati H 2008 Monatsh. Chem. 139935

50. Sangshetti J N, Kokare N D, Kotharkara S A and Shinde D B 2008 J. Chem. Sci. 120463

51. Shaabani A, Maleki A and Behnam M 2009 Synth. Commun. 39102

52. Wang L and Cai C 2009 Monatsh. Chem. 140541

53. Samai S, Nandi G C, Singh P and Singh M S 2009 Tetrahedron 6510155

54. Paone D V and Shaw A W 2008 Tetrahedron Lett. 49 6155

55. Hayes J F, Mitchel M B and Wicks C 1994 Heterocyclic 38575

56. Revesz L, Bonne F and Makavou P 1998 Tetrahedron Lett. 395171

57. Liverton N J, Butcher J W, Claiborne C F and Claremon D A $1999 \mathrm{~J}$. Med. Chem. 422180

58. Khodaei M M, Bahrami K and Kavianinia I $2007 \mathrm{~J}$. Chin. Chem. Soc. $\mathbf{5 4} 829$ 